\title{
MECHANISMS OF ENDOCRINOLOGY Endocrinology of opioids
}

\author{
Athanasios Fountas ${ }^{1,2,3}$, Shu Teng Chai ${ }^{1,2,3}$, Chrysoula Kourkouti ${ }^{2,3}$ and Niki Karavitaki ${ }^{1,2,3}$ \\ ${ }^{1}$ Institute of Metabolism and Systems Research, College of Medical and Dental Sciences, University of Birmingham, \\ Birmingham, UK, ${ }^{2}$ Centre for Endocrinology, Diabetes and Metabolism, Birmingham Health Partners, Birmingham, \\ UK, and ${ }^{3}$ Department of Endocrinology, Queen Elizabeth Hospital, University Hospitals Birmingham NHS Foundation \\ Trust, Birmingham, UK \\ Correspondence \\ should be addressed \\ to N Karavitaki \\ Email \\ n.karavitaki@bham.ac.uk
}

\begin{abstract}
The use of opioids has grown substantially over the past two decades reaching the dimensions of a global epidemic. These drugs have effects on multiple levels of the endocrine system through mechanisms which are still not fully elucidated, and awareness of their endocrine sequelae is vital for all specialists prescribing or managing patients on them. Hypogonadism is the most well-recognised consequence of opioid use (prevalence $21-86 \%$ ) which, however, may remain undiagnosed with potential adverse outcomes for the patients. Although less frequent, cortisol deficiency can also be found. Furthermore, there is a negative impact on bone health (with reduced bone mineral density and increased fracture risk) and occasionally hyperprolactinaemia, whereas the clinical significance of alterations in other hormones remains to be clarified. Discontinuation or reduction of the opioid and, in cases of chronic pain, consideration of alternative therapies for pain relief are potential management options. Hormonal replacement, especially when the above measures are not practically feasible, needs to be considered. Further studies are needed to clearly establish the prevalence of hormonal abnormalities with various regimes, doses and routes of opioids and to address reliably the long-term benefits and risks of hormonal treatment in patients on opioids. Until evidence-based, safe and cost-effective clinical guidelines become available, periodical assessment of the gonadal and adrenal function (particularly when relevant clinical manifestations are present) and evaluation of the bone health status are advised.
\end{abstract}

\section{Introduction}

Opium is acquired in the dried latex form from the seed pod of the opium poppy (Papaver somniferum), initially cultivated by the Sumerians at around 4000 BC. The naturally occurring alkaloids of opium and the drugs synthesized from it are described as 'opiates', whilst all natural or synthetic chemicals that bind to opioid receptors are included in the term 'opioids'. The main classes of opioids include natural opiates (alkaloids in the resin of the opium poppy, mainly morphine, codeine and thebaine), esters of morphine (e.g. morphine

\section{Invited Author's profile}

Niki Karavitaki, MSc, PhD, FRCP is Senior Clinical Lecturer in the Institute of Metabolism and Systems Research, College of Medical and Dental Sciences at the University of Birmingham andHonorary Consultant Endocrinologist at the Queen Elizabeth Hospital, Birmingham, UK. Her research interest is on hypothalamo-pituitary disease with particular focus on pituitary tumours and hypopituitarism.

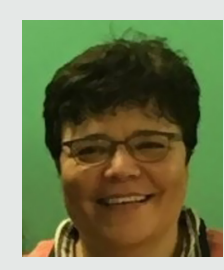

(C) 2018 European Society of Endocrinology Printed in Great Britain
Published by Bioscientifica Ltd. 
diacetate or diamorphine (heroin)), semi-synthetic opioids (produced from the natural opiates or morphine esters, e.g. hydromorphone, hydrocodone, oxycodone, oxymorphone, buprenorphine), fully synthetic opioids (e.g. fentanyl, pethidine, methadone, tramadol) and endogenous opioid peptides produced in the body (e.g. endorphins, enkephalins) (1).

Opioids exert their actions by binding to receptors which belong to the family of G-protein-coupled ones, and their activation produces a range of different effects (1). There are many types of opioid receptors with the three main being $\mu, \kappa$ and $\delta$ (that are naloxone sensitive), whereas the nociceptin receptor, with effects not reversed by naloxone, was discovered in 1994 (2). The opioids used in clinical practice have various indications and are mainly offered as analgesic agents (Table 1), whereas heroin is used as a recreational drug due to its euphoric effects (illicit use). The most commonly available opioids (morphine, codeine, fentanyl, and their derivatives, as well as methadone, tramadol and pethidine) are primarily $\mu$-receptors agonists, whilst buprenorphine and pentazocine are mixed agonists/ antagonists (3). Pentazocine acts as a partial agonist on $\delta$ - and $\kappa$-receptors and as an antagonist on the $\mu$-receptor, whilst buprenorphine has partial agonist activity on $\mu$ - and nociceptin receptors and antagonist activity on к-receptors (4).

The use of opioids has grown over the past two decades; between 2000 and 2014, it increased 216\% in USA and 210\% globally making opioid consumption a real global epidemic (5). Notably, in 2014, USA used around $69 \%$ of the world's supply of opioids; prescribers involve a wide range of health professionals including pain physicians, family physicians, orthopaedic surgeons, anaesthesiologists, psychiatrists, physical medicine and rehabilitation specialists (5). Data from the UK Clinical Practice Research Datalink confirm a significant rise in strong opioid prescriptions (buprenorphine, fentanyl, morphine and oxycodone) between 2000 and 2010, with the majority administered for non-cancer patients (6); in this report, the number of strong opioid users increased from 9479 to 53666 during the study period. In addition, prescription of long-acting opioids in patients with chronic non-cancer pain has been associated with a significantly elevated risk of all-cause and of cardiovascular-specific mortality, compared with analgesic anticonvulsants or low-dose tricyclic antidepressants $(5,7)$.

Exogenous opioids can have various effects on the endocrine system, which, nonetheless, may remain underdiagnosed with potential adverse sequelae for the patients. The aim of this manuscript is to provide a review of these effects and their underlying mechanisms, to discuss their clinical significance and management and to identify areas requiring further research in this field.

\section{Hypothalamo-pituitary-gonadal axis}

Opioids, both endogenous and exogenous, modulate gonadal function primarily by acting on opioid $\varepsilon$-receptors in the hypothalamus (8). This leads to reduced release or disruption of the normal pulsatility of gonadotropinreleasing hormone (GnRH) secretion and reduction of the release of luteinising hormone (LH) and folliclestimulating hormone (FSH - to a lesser extent) from the pituitary gland, and of testosterone or oestradiol from the gonads $(9,10,11,12,13,14,15,16)$. Opioids may also directly inhibit the pituitary release of gonadotropins (17). Hyperprolactinaemia that can be occasionally caused by opioids may contribute to their suppressive effects on the hypothalamo-pituitary-gonadal (HPG) axis (9). Opioids have also direct effects on the gonads: these include decreased production of sperm, testicular interstitial fluid and intra-testicular testosterone (18).

The effects of long-term opioid use on the gonadal status have been studied extensively in the past four decades and the reported prevalence of opioid-induced hypogonadism ranges between $21 \%$ and $86 \%(10,11,12$, $13,14,15,16,19)$. This wide range is attributed to the heterogeneity of the studies (differences in the populations assessed, variations in the type, dose, route and duration of opioid administration, potential impact of pain, of other comorbidities and of concurrent medications and possibly differences in the age of the patients included).

The initial studies involved mainly heroin addicts and patients on methadone for maintenance and had demonstrated reduction of testosterone levels in males, with an associated reduction in LH and/or FSH $(20,21$, 22). The decrease in testosterone occurs within a few hours of opioid administration; in a study of 13 males on acetylmethadol for opioid dependence, there was significant reduction of testosterone $4 \mathrm{~h}$ after the ingestion of the drug, with the levels remaining low around $24 \mathrm{~h}$ after the drug administration and returning to baseline values $48 \mathrm{~h}$ post acetylmethadol use (23). Woody et al. had similar results, albeit the duration of recovery was shorter (11). In another study with male heroin addicts, recovery of testosterone to normal occurred after about 1 month of drug abstinence (21). Furthermore, methadone has a dose-dependent effect on the testosterone levels of heroin 
Table 1 Types, administration routes and indications of opioids according to British National Formulary (British National Formulary, (Online). Available: https://bnf.nice.org.uk. (Accessed: 24-Mar-2018).

\begin{tabular}{|c|c|c|}
\hline Opioid & Administration route & Indications \\
\hline Alfentanil & Intravenous & $\begin{array}{l}\text { Analgesia and enhancement of anaesthesia during operation } \\
\text { Analgesia and suppression of respiratory activity in ventilated } \\
\text { patients }\end{array}$ \\
\hline Buprenorphine & $\begin{array}{l}\text { Oral } \\
\text { Sublingual } \\
\text { Intramuscular } \\
\text { Intravenous } \\
\text { Transdermal }\end{array}$ & $\begin{array}{l}\text { Acute or chronic pain } \\
\text { Premedication before surgery } \\
\text { Intra-operative analgesia } \\
\text { Opioid dependence }\end{array}$ \\
\hline Codeine & $\begin{array}{l}\text { Oral } \\
\text { Intramuscular }\end{array}$ & $\begin{array}{l}\text { Acute pain } \\
\text { Unproductive cough } \\
\text { Acute diarrhoea }\end{array}$ \\
\hline Diamorphine (heroin) & $\begin{array}{l}\text { Subcutaneous } \\
\text { Intramuscular } \\
\text { Intravenous } \\
\text { Rectal }\end{array}$ & $\begin{array}{l}\text { Acute or chronic pain } \\
\text { Myocardial infarction } \\
\text { Pulmonary oedema }\end{array}$ \\
\hline Dihydrocodeine & $\begin{array}{l}\text { Oral } \\
\text { Subcutaneous } \\
\text { Intramuscular }\end{array}$ & Acute or chronic pain \\
\hline Dipipanone & Oral & Acute pain \\
\hline Fentanyl & $\begin{array}{l}\text { Sublingual } \\
\text { Buccal } \\
\text { Intravenous } \\
\text { Intranasal } \\
\text { Transdermal }\end{array}$ & $\begin{array}{l}\text { Chronic pain } \\
\text { Breakthrough pain in patients receiving opioid therapy for } \\
\text { chronic cancer pain } \\
\text { Analgesia and enhancement of anaesthesia during operation } \\
\text { Analgesia and suppression of respiratory activity in ventilated } \\
\text { patients }\end{array}$ \\
\hline Hydromorphone & Oral & Acute or chronic pain \\
\hline Meptazinol & $\begin{array}{l}\text { Oral } \\
\text { Intramuscular } \\
\text { Intravenous }\end{array}$ & $\begin{array}{l}\text { Acute pain } \\
\text { Obstetric analgesia }\end{array}$ \\
\hline Methadone & $\begin{array}{l}\text { Oral } \\
\text { Subcutaneous } \\
\text { Intramuscular }\end{array}$ & $\begin{array}{l}\text { Chronic pain } \\
\text { Opioid dependence } \\
\text { Cough in terminal disease }\end{array}$ \\
\hline Morphine & $\begin{array}{l}\text { Oral } \\
\text { Subcutaneous } \\
\text { Intramuscular } \\
\text { Intravenous } \\
\text { Rectal }\end{array}$ & $\begin{array}{l}\text { Acute or chronic pain } \\
\text { Premedication before surgery } \\
\text { Cough in terminal disease } \\
\text { Myocardial infarction } \\
\text { Pulmonary oedema }\end{array}$ \\
\hline Oxycodone & $\begin{array}{l}\text { Oral } \\
\text { Subcutaneous } \\
\text { Intravenous }\end{array}$ & Acute or chronic pain \\
\hline Papaveretum & $\begin{array}{l}\text { Subcutaneous } \\
\text { Intramuscular } \\
\text { Intravenous }\end{array}$ & $\begin{array}{l}\text { Chronic pain } \\
\text { Premedication before surgery } \\
\text { Postoperative analgesia }\end{array}$ \\
\hline Pentazocine & $\begin{array}{l}\text { Oral } \\
\text { Subcutaneous } \\
\text { Intramuscular } \\
\text { Intravenous }\end{array}$ & Acute or chronic pain \\
\hline Pethidine (meperidine) & $\begin{array}{l}\text { Oral } \\
\text { Subcutaneous } \\
\text { Intramuscular } \\
\text { Intravenous }\end{array}$ & $\begin{array}{l}\text { Acute pain } \\
\text { Obstetric analgesia } \\
\text { Premedication }\end{array}$ \\
\hline Remifentanil & Intravenous & $\begin{array}{l}\text { Analgesia and enhancement of anaesthesia during operation } \\
\text { Analgesia and sedation in ventilated patients }\end{array}$ \\
\hline Sufentanil & Sublingual & Acute pain \\
\hline Tapentadol & Oral & Acute or chronic pain \\
\hline Tramadol & $\begin{array}{l}\text { Oral } \\
\text { Intramuscular } \\
\text { Intravenous }\end{array}$ & Acute or chronic pain \\
\hline
\end{tabular}


addicts on methadone detoxification (22). In female heroin addicts, amenorrhoea and galactorrhoea may be present (24); nonetheless, series systematically assessing this group of patients are not available.

Hypogonadism is also present in both male and female patients on opioids (oral, transdermal or intrathecal) for cancerous or non-cancerous pain in cohort or crosssectional studies; it should be noted, however, that other factors may also contribute to the hypogonadism including pain pathophysiology, pain comorbidities and patients' age, and these need to be taken into account when interpreting their results $(12,13,14,16,25,26$, $27,28,29)$. The effects on the HPG axis begin as soon as the opioid is taken $(12,13,16,30)$ and the hormonal changes are dose related $(13,31)$. The resultant clinical manifestations include erectile dysfunction, decreased libido, infertility, fatigue, depression, hot flushes and night sweats in males $(13,16,27,28,29)$ and reduced libido, ameno- or oligomenorrhoea with anovulation in premenopausal females (16). In postmenopausal women, LH and FSH levels can be decreased (16). The prevalence of hypogonadism is higher in men than in women taking oral opioids for chronic non-cancer pain (15). In premenopausal chronic pain patients, the suppression of LH may be less profound when opioids are administered orally/transdermally compared with the intrathecal route (9). Notably, chronic use of longacting opioids is associated with greater odds of androgen deficiency compared to chronic use of short-acting ones $(31,32)$. Furthermore, transdermal fentanyl, methadone and oxycodone (long- and short-acting formulations combined) are associated with higher odds of androgen deficiency when compared to hydrocodone (33). It should be pointed out, however, that these findings reflect the observations at the doses used for different opioids in the various studies. Buprenorphine used as maintenance for opioid dependence or for the management of acute/ persistent pain results in less severe hypogonadism when compared to methadone $(34,35)$. Reduction in the dose or cessation of therapy reverses the hypogonadism (26, $30,36,37)$ but the time course of this has not been systematically studied.

Despite the abundance of evidence indicating that opioids lead to hypogonadotropic hypogonadism, this condition remains underdiagnosed in daily practice; this may relate with lack of symptoms reporting by the patients combined with the underappreciation of this common problem amongst the clinicians. Currently, there is no consensus or clinical guidelines for the diagnosis and management of opioid-induced hypogonadism.
Manifestations of hypogonadism should be enquired before, as well as during opioid treatment and patients should be educated on this potential side effect and encouraged to report hypogonadal symptoms should they experience any. Laboratory evaluations need to be taken periodically (and also when changing dose or regime of opioid) and include measurement of blood testosterone (in a morning sample before $10 \mathrm{am}$ ) and gonadotropins in men and oestradiol and gonadotropins in women (combined with menstrual history) (38). Measurement of prolactin (PRL) and taking into account the impact of other medications and comorbidities, as well as exclusion of other causes of hypogonadotropic hypogonadism are also advised.

Management of the opioid-induced hypogonadism includes discontinuation or reduction of the dose of the opioid and consideration of alternative therapies for patients on chronic pain requiring pain relief. When the above measures are not viable, gonadal hormone replacement should be considered with a number of studies showing beneficial effects. Aloisi et al., in a series of nine males (aged between 44 and 75 years) on epidural morphine for non-oncological chronic pain treated with testosterone gel for 12 months, demonstrated improvement in the sexual dimension of the Aging Males' Symptoms scale and in the Mental Index of the SF-36 questionnaire (39). The patients also reported increase in the growth of body hair and improved appetite, and their prostate-specific antigen (PSA) levels remained within normal limits. None of the Profile of Mood State subscale scores or Centre for Epidemiological Studies Depression Scale ratings showed significant changes (39). Daniell et al., in an open-label pilot study on 16 men (aged between 34 and 55 years) with opioid-induced androgen deficiency (on oral sustained release oxycodone or oral methadone for pain syndromes) offered testosterone transdermal patches for 24 weeks, found improvement in androgen deficiency symptoms, sexual function, psychological wellbeing and depressed mood by using validated questionnaires, as well as of the haemoglobin and haematocrit (40). Basaria et al., in a randomised, double-blind, parallel placebo-controlled trial of 65 males (aged between 18 and 64 years) with opioidinduced androgen deficiency and chronic non-cancer pain, randomised to receive transdermal testosterone or placebo for 14 weeks, found that men in the testosterone arm demonstrated greater improvement in mechanical and pressure hyperalgesia and in sexual desire, as well as reduction in fat mass (41); elevation in PSA $>4 \mathrm{ng} / \mathrm{mL}$ was seen in two patients, one in each group and erythrocytosis 
occurred in neither group. Notably, Huang et al., in a placebo-controlled, double-blind randomized trial from the same centre of 64 non-diabetic men (aged between 18 and 64 years) on opioid analgesics for chronic noncancer pain and morning total testosterone $<12 \mathrm{nmol} / \mathrm{L}$ (as measured by liquid chromatography-tandem mass spectrometry), randomised to 14 weeks of transdermal testosterone gel or placebo gel daily, found that changes in lipid profile, fasting glucose and insulin, homeostatic model assessment for insulin resistance and C-reactive protein were similar from baseline to the end of treatment in both groups; glucose and insulin response to $75 \mathrm{~g}$ oral glucose load, inflammatory markers and adipokines also did not differ between the two groups (42). However, the duration of this study was not long enough to evaluate cardiovascular safety of testosterone therapy in these patients. In contrast to their male counterparts, series looking at gonadal hormone replacement in opioidinduced hypogonadism in women are not available.

In summary, opioid use has an inhibitory effect on the HPG axis through action at various levels leading to hypogonadism. Discontinuation or reduction in the dose of opioid can reverse this sequela but when this is not possible, gonadal hormone treatment needs to be considered. Adequately powered well-designed studies are needed to establish the long-term benefits and risks of hormone replacement in this group of patients, as well as the potential impact of hormonal treatment on pain sensitivity and on the recovery of patients on methadone for opioid use disorder.

\section{Hypothalamo-pituitary-adrenal axis}

Opioids suppress the hypothalamo-pituitary-adrenal (HPA) axis mainly at the hypothalamic-pituitary level by inhibiting corticotropin-releasing hormone (CRH) and vasopressin secretion and by reducing their effect on adrenocorticotropic hormone (ACTH) and cortisol release $(43,44,45,46,47)$. The receptors involved are not entirely known but $\kappa$ - are considered to be the predominant type; $\delta$-receptors have also been implicated $(8,48,49)$. Nonetheless, the increasing evidence of secondary adrenal insufficiency in patients receiving $\mu$-receptor agonists suggests a potential role of this subtype in the opioid-induced regulation of HPA axis (morphine, hydromorphone, methadone, tramadol, diamorphine, fentanyl and loperamide act predominantly through this receptor) $(36,37,50,51,52,53,54)$. This is also supported by the observation that human subjects carrying the A118G SNP of the $\mu$-receptor encoding gene OPRM1 (which has been shown to increase the receptor's binding affinity to $\beta$-endorphin) show blunted ACTH response to metyrapone and exaggerated cortisol release to naloxone $(55,56)$. Opioids have also direct effects on the adrenal glands, independently of their effect on the hypothalamo-pituitary unit; naloxone administration in patients with hypothalamo-pituitary disconnection led to higher cortisol (but not ACTH) levels compared with saline (57) and $\beta$-endorphin suppressed ACTH-stimulated cortisol production in isolated human adrenocortical cells (58).

Acute administration of opioids in animals results in an exaggerated response of the HPA axis, which may be followed by a rebound decrease of its activity $(59,60)$. Data from animal studies assessing the effects of chronic administration of opioids on ACTH and glucocorticoid release are conflicting showing activation (61), suppression (59) or no effect (62).

Single administration of various opioids (morphine, heroin, buprenorphine, remifentanil) in normal subjects results in suppression of ACTH and glucocorticoid secretion, blunted pituitary-adrenal response to $\mathrm{CRH}$, and diminished cortisol response to psychosocial or surgical stress $(45,46,63,64,65)$. Notably, gender may play a role in the effect of opioids on the HPA axis. Women demonstrate a greater sensitivity to opioid receptor antagonists (naloxone and naltrexone) on their cortisol response compared to men suggesting sex differences in the endogenous opioid system $(66,67,68)$. Menstrual cycle may also be implicated with a study showing that women in the luteal phase of their cycle had greater naltrexone-induced increases in serum cortisol than women in the early follicular phase (69).

In addition, diamorphine has an acute suppressive effect on HPA axis in heroin-dependent addicts on heroin-ssisted treatment (70). Opioid-dependent patients on maintenance treatment with intravenous diacetylmorphine have reduced serum levels of vasopressin and cortisol compared to healthy controls (43). It is of note that in heroin addicts, there is a disturbed cortisol circadian rhythm with lower morning cortisol levels compared with controls $(65,71)$.

Several case reports documenting secondary adrenal insufficiency after oral or transdermal opioid administration of variable duration (including even of a few days) mainly for pain relief have been published (36, $37,50,51,52,53,54)$. The accurate prevalence of adrenal insufficiency in these patients has not been clearly defined and chronic pain can be a major confounder (chronic 
pain has been associated with loss of the diurnal variation of blood cortisol, lower morning blood cortisol and 24-h urinary free cortisol levels compared with controls and hyper-reactive ACTH release to CRH stimulation) $(72,73)$. Aloisi et al. showed that intrathecal administration of morphine $(0.9 \mathrm{mg} /$ day) for 15 days in patients with persistent severe pain led to reduction in the blood cortisol levels with an immediate effect from Day 1 to Day 15 in both sexes; the levels rose on Day 16, $24 \mathrm{~h}$ after the opioid withdrawal (30). In contrast, transdermal buprenorphine ( $35 \mu \mathrm{g} / \mathrm{h}$ every $72 \mathrm{~h}$ ) for acute/persistent pain for 6 months did not inhibit the HPA axis. Gibb et al. in a series of 48 patients attending chronic tertiary pain clinics and treated with long-term opioid analgesia (tramadol, oxycodone, morphine sulphate, fentanyl or buprenorphine patch, dihydrocodeine - median daily opioid dose of $68 \mathrm{mg}$ as determined by morphine sulphate equivalent dose) for at least 6 months and no recent exposure to exogenous glucocorticoids, found $8.00 \mathrm{~h}$ blood cortisol $<100 \mathrm{nmol} / \mathrm{L}$ in $8 \%$ of them and failure to respond to synthetic ACTH stimulation (peak cortisol $<430 \mathrm{nmol} / \mathrm{L}$ ) in $6 \%(74)$. When focusing on the 33 patients on high-dose opioid analgesia (excluding tramadol and dihydrocodeine), approximately $10 \%$ of those assessed had an initial suboptimal cortisol response to synthetic ACTH. Intrathecal administration of morphine or hydromorphine in 72 patients with non-malignant pain (mean daily dose $4.8 \pm 3.2 \mathrm{mg}$ and mean duration of treatment $26.6 \pm 16.3$ months) resulted in basal cortisol levels $<5 \mu \mathrm{g} / \mathrm{dL}$ and peak cortisol value $<18 \mu \mathrm{g} / \mathrm{dL}$ during an insulin tolerance test (ITT) in $9 \%$ and $15 \%$ of them respectively (16); one of the patients in this series developed Addisonian crisis during pneumonia. Furthermore, 33\% of 20 chronic pain patients receiving chronic pump intrathecal morphine infusion $(0.2-10 \mathrm{mg} /$ day) and $50 \%$ of 20 patients on oral morphine $(60-120 \mathrm{mg} /$ day) demonstrated hypoadrenalism (defined as stimulated cortisol levels during ITT $<18 \mu \mathrm{g} / \mathrm{dL}$ ) (75). Additionally, there is reduction of the adrenal androgen DHEAS levels during opioid therapy in patients with chronic non-malignant pain $(14,75,76)$. Factors predicting the development of abnormal cortisol stress response are not as yet established. However, given the widespread use of opioids, it is anticipated that a large number of patients are possibly at risk of cortisol deficiency.

The altered HPA axis function of opioid users improves or returns to normal after discontinuation or reduction in the dose of the drug $(36,37,50,51,53,54)$, but the time interval of this has not been systematically studied. Interestingly, Nenke et al., in a pilot, randomized, doubleblind, placebo-controlled crossover study with 17 patients on long-term opioid therapy for chronic non-cancer pain and mild hypocortisolism (defined by a plasma cortisol response $\leq 350 \mathrm{nmol} / \mathrm{L}$ at $60 \mathrm{~min}$ following a cold pressor test), found that hydrocortisone therapy $\left(10 \mathrm{mg} / \mathrm{m}^{2} /\right.$ day) led to improvement in vitality and pain tolerance compared to placebo (77).

In summary, opioids exert inhibitory actions on the HPA axis by acting at various levels. Although it could be argued that hypocortisolism is an adaptive response to opioids, the reported cases of improvement of clinical manifestations resembling those of cortisol deficiency after glucocorticoid administration $(52,53,74,77)$ and the description of Addisonian crises whilst on these agents (16, 54) suggest that, at least in some patients, hypocortisolism is of clinical significance. Further studies are needed to define the prevalence of hypoadrenalism with different opioids at various regimes and routes, to establish the clinical significance and potential consequences/adverse outcomes of the biochemical findings (particularly if these reflect modest changes in the HPA axis) and to provide clear guidance on the reversibility and the time course of the hormonal changes following withdrawal or reduction of opioid dose. Although the existing literature cannot provide robust evidence for safe and cost-effective clinical guidelines, patients on opioids should be considered at risk of hypoadrenalism and checking an early morning plasma cortisol (particularly in the presence of relevant clinical manifestations) is a sensible approach. Further dynamic assessment of the HPA axis will depend on the results of the basal cortisol. The frequency of the HPA axis assessment is not known but certainly the presence of symptoms/signs of cortisol deficiency should prompt investigations towards this direction.

\section{Somatotroph axis}

In animal models, acute opioid administration stimulates growth hormone $(\mathrm{GH})$ secretion $(78,79)$. On the other hand, chronic administration has led to no $(61,80)$ or to stimulatory effect (81). Studies on the pathways and mechanisms involved on the effects of opioids on GH release show that various types of opioid receptors $(\mu, \kappa$, $\delta$ ) are implicated, but their activation effects vary between reports $(82,83,84)$. A reset of the hypothalamic GH pulse generator via opioid receptor stimulation is also a possible mechanism (85). Treatment of rats with antiserum against growth hormone-releasing hormone (GHRH) inhibited the GH stimulatory response to different types of opiates $(86,87)$. In addition, opioids exert inhibitory effect on 
somatostatin release (88) and action (89). Finally, chronic treatment with morphine decreased GH mRNA levels in rat pituitary and concomitant administration of naloxone inhibited this (90). Notably, gender may influence the effects of these drugs on the GH secretory dynamics. Continuous morphine exposure of male rats resulted in increased basal and mean GH concentrations, as well as in a modest increase of the GH pulse frequency but not of pulse amplitude; in females, morphine, apart from a marked reduction in the pulse amplitude, had little effect on other parameters of GH secretion (91).

In human subjects, there are acute stimulatory effects of opioids on GH secretion which relate with the dose offered $(92,93)$. Thus, intravenous morphine at doses of $5 \mathrm{mg}$ and $10 \mathrm{mg}$ did not promote $\mathrm{GH}$ secretion but a higher dose of $15 \mathrm{mg}$ did $(92,94,95)$. Notably, administration of a Met-enkephalin analogue G-DAMME, in healthy men combined with a maximally stimulatory dose of a GHRH analogue resulted to an enhancing effect of the GHRHinduced GH release, suggesting that other mechanisms are also implicated (93). Data on possible sex differences are contradictory. Naloxone infusion decreased GHRHinduced GH release in healthy women but had no effect in normal men (96). On the other hand, in another study, naloxone significantly blunted the GH response to GHRH in healthy male volunteers (97).

Humans treated with intrathecal opioids (morphine and hydromorphine) for non-malignant pain had significantly lower serum insulin-like growth factor 1 (IGF-1) levels compared with controls; $17 \%$ of the subjects had IGF-1 concentrations more than two standard deviations below the mean, whilst $15 \%$ of them showed peak GH $<3 \mu \mathrm{g} / \mathrm{L}$ during ITT (16). Abnormal GH response on ITT was also detected in 26\% of methadone-treated patients and in $31 \%$ of heroin addicts (98). In this study, a maximal level of GH $>9 \mu \mathrm{g} / \mathrm{L}$ or an increment over the baseline $>10 \mu \mathrm{g} / \mathrm{L}$ were defined as criteria of a normal response; using the cut-off of $<3 \mu \mathrm{g} / \mathrm{L}$, a compromised GH response would be found in $5 \%$ and $6 \%$ of methadone and heroin users, respectively. Finally, chronic pain patients on oral opioids had no abnormal IGF-1 levels or a difference in GH response to the glucagon stimulation test when compared to a control group receiving non-opioid analgesia (99); a suboptimal GH response found in two cases was finally attributed to obesity.

The above data demonstrate the complexity of the effects and relevant mechanisms of opioids on the GH axis. Overall, acute administration of opioids increases $\mathrm{GH}$ secretion but the impact of chronic use varies considerably. Gender, opioid type, route and dose are factors that influence the action of opioids on GH release. The clinical significance of these findings in patients using long-term opioids remains to be elucidated.

\section{Prolactin}

Opioids can have a stimulatory effect on PRL secretion mediated by $\mu$-, $\kappa-$ and $\delta$-opioid receptors in the hypothalamus (100).

Acute administration (oral or intravenous) of morphine increases PRL in healthy men (101) and postmenopausal women (94). In women, sex steroids may alter the opioid-induced effects on PRL secretion; thus, whilst naloxone had no effect on PRL secretion in postmenopausal and hypogonadal women, as well as women in the early follicular phase of the menstrual cycle, when administered for 7 days in the luteal phase, it induced PRL release (9).

In chronic use of opioids, the effects are variable. PRL levels have been found to be high in opioid addicted subjects and in opium smokers $(18,102,103)$. Furthermore, oral opioids for chronic pain increase PRL $(104,105)$. On the other hand, morphine offered intrathecally for chronic non-cancer pain had no effect on PRL (16). Finally, buprenorphine or methadone maintenance therapy for opioid dependence did not lead to high PRL $(34,106)$.

Opioid-induced hyperprolactinaemia can lead to painful gynaecomastia, galactorrhoea and hypogonadism (104).

Bromocriptine has been successfully used in cases of hyperprolactinaemia due to opioid use (107).

Overall, high PRL can be detected in patients on opioids, although the effect of pain on this finding needs to be taken into account. The frequency of hyperprolactinaemia and the impact of dose, route and type of drug have not been clearly established, but the clinician needs to be aware of this potential consequence and its clinical sequelae (particularly on the gonadotroph axis).

\section{Hypothalamo-pituitary-thyroid axis}

Based on most animal studies, opioids have inhibitory effect on thyroid-stimulating hormone (TSH) secretion, and this is observed mainly with pharmacological doses $(108,109)$. 
In humans, acute intravenous administration of morphine in normal volunteers led to a significant increase in serum TSH and enhanced the response of TSH to thyrotropin-releasing hormone stimulation (110).

In chronic use of opioids for cancer pain and in opioid addicts, there was no difference in basal levels of TSH and peripheral thyroid hormones compared with controls (16, $104,111,112)$. However, opium smokers had lower TSH levels compared with healthy volunteers (102).

The potential clinical significance and the implications of these data remain to be elucidated and, therefore, at this stage, clinical recommendations cannot be provided.

\section{Arginine vasopressin}

Opioids affect arginine vasopressin (AVP) secretion through $\mu$ - (113) and possibly к-opioid receptors (114).

Acute opioid administration can lead to a rise in AVP levels. Fentanyl offered in two continuous intravenous infusions in five healthy volunteers increased plasma AVP in a dose-dependent manner (115). Notably, a case of a patient on fentanyl patches who developed syndrome of inappropriate antidiuretic hormone secretion has been published (116).

Boulton et al. showed that in patients undergoing coronary artery bypass surgery, the levels of AVP were significantly higher with fentanyl than with sufentanil during induction of anaesthesia (117). Administration of extradural injection of morphine $6 \mathrm{~h}$ after surgery in six patients produced increase in plasma AVP (118). Bozkurt et al., in a series of children undergoing surgery (major genito-urinary or abdominal operations), found that both a single dose of epidural morphine post-induction or morphine infusion led to increase in serum ADH levels (119).

Overall, the studies on the impact of exogenous opioids on AVP in humans are confounded by the differences in the fluid status of the subjects, as well as by the side effects of opioids, including hypotension and nausea, which can stimulate AVP release. Therefore, the interpretation of the published data and the extraction of robust conclusions for clinical practice remain challenging.

\section{Bone mineral density and fracture risk}

Exogenous opioids have a negative impact on bone health. Opioid-induced hypogonadism, as well as direct action of these drugs on bone formation are potential contributing factors. Osteoblasts express opioid receptors and opioids inhibit the growth of human osteoblast tissue cultures; this effect was prevented by opioid antagonists (120). Furthermore, opioids inhibit osteocalcin production in osteoblast tissue cultures (120).

Male chronic heroin users have significantly lower vertebral bone mineral density (BMD) compared with healthy age- and sex-matched control subjects (121). In a cross-sectional study of patients taking methadone maintenance therapy, BMD was lower from control values throughout the skeleton in men but not in women; notably in this series, the male patients had lower serum testosterone than the controls (122). In another study, $50 \%$ of men and $21 \%$ of women on chronic oral opioids had osteopenia; in this report, however, males had used opioids for a longer period and had higher prevalence of hypogonadism compared with women (15). In addition, in a study of 14 males on intrathecal opioids for chronic non-malignant pain and hypogonadism, osteoporosis was observed in $21 \%$ and osteopenia in 50\% (25). In a cross-sectional analysis of adults aged 17 years and older from the Third National Health and Nutrition Examination Survey, opioids were associated with significantly reduced BMD besides anticonvulsants (123).

In a case-control study from a nation-wide register in Denmark, there was increased fracture risk in users of morphine and other opioids (124). Notably, the authors suggested that this increase, which was observed even on very low doses, may be related with the risk of falls owing to the acute central nervous system effects of opioids (124). This view was further supported by a nested case-control study using the UK-based General Practice Research Database in which a clear dose-response relationship between current cumulative opioid use and risk of fracture was found (125); thus, current light use of opioids was associated with increased risk of fractures in adults with non-cancer pain, particularly during the initial weeks of administration, whilst current heavy cumulative opioid use was not, particularly in women (125). Finally, the contribution of limitations in mobility (due to chronic pain) on the higher risk of fractures cannot be excluded.

There is no consensus on the monitoring of the BMD in patients on opioids but those with risk factors and particularly hypogonadism require assessment. Discontinuing the opioid, if possible, and treatment of osteoporosis or osteopenia according to the current guidelines are management approaches. 


\section{Conclusions and future perspectives}

Exogenous opioids have effects on multiple levels of the endocrine system through mechanisms which are still not fully elucidated (Table 2). Hypogonadism is the most well-recognised consequence of opioid use which, however, may remain undiagnosed with potential adverse sequelae for the patients. Although less frequent, cortisol deficiency can be found. The data on the impact of opioids on GH and TSH are less clear and often complex, whereas hyperprolactinaemia can be occasionally detected. AVP levels may be increased in patients on these drugs but a number of confounding factors do not allow clear conclusions to be drawn. Of particular importance is the negative impact of opioids on bone health, which may be overlooked during the care of these patients.

Table 2 Key findings on impact of exogenous opioids on anterior pituitary hormone axes, proposed investigations and management.

\section{Key findings}

Hypothalamo-pituitary-gonadal axis

- Inhibitory effect

- Hypogonadotrophic hypogonadism

Hypothalamo-pituitary-adrenal axis

- Inhibitory effect

- Low basal blood cortisol levels/inadequate response of cortisol on dynamic testing

- Clinical significance of these findings not established: adaptive response to opioids? true cortisol deficiency?

- Cases of Addisonian crises or with symptomatology resembling adrenal insufficiency showing clinical improvement after glucocorticoid administration have been reported

Somatotroph axis

- Stimulatory effect after acute administration in normal human subjects

- Inhibitory (compromised response on dynamic testing) or no effect after administration for therapeutic purposes in heroin addicts

- Clinical significance of these findings not clear and, at present, the benefits of assessment of the somatotroph axis and of offering growth hormone replacement have not been established

Prolactin

- Stimulatory or no effect
Proposed investigations

Males*

Blood testosterone (08:00-10:00 h sample), FSH, LH

Females*

Blood oestradiol, FSH, LH (combined with menstrual history)

08:00-09:00 h blood cortisol \pm dynamic assessment of the hypothalamo-pituitaryadrenal axis (following confirmation of relevant clinical manifestations and consultation with endocrinologist)
Management

Discontinuation or reduction of dose of opioid If above not viable, consider gonadal hormone replacement

Discontinuation or reduction of dose of opioid Glucocorticoid replacement in cases of biochemically confirmed adrenal insufficiency with reassessment of the axis if discontinuation or reduction in dose of opioid has taken place
Blood prolactin**

\begin{abstract}
Assess impact on gonadal axis and presence of galactorrhoea, gynaecomastia Consider discontinuation, reduction in dose, or alternative opioid if needed
\end{abstract}

Hypothalamo-pituitary-thyroid axis

- No effect after administration for therapeutic purposes or in opioid addicts

- Lower TSH levels in opium smokers compared with healthy volunteers: clinical significance unknown

*Other causes of hypogonadotrophic hypogonadism need to be excluded (36); **impact of pain or of other medications need to be taken into account. FSH, follicle-stimulating hormone; LH, luteinising hormone. 
Discontinuation or reduction of the opioid and, in cases of chronic pain, consideration of alternative therapies for pain relief are potential management options. Hormonal replacement, especially when the above measures are not practically feasible, needs to be considered (Table 2). Awareness of the endocrine effects of opioids by all specialists prescribing or managing patients on these drugs is vital, particularly given the expanding dimensions of this problem as a global epidemic.

Further research is needed to clearly establish the prevalence of hormonal abnormalities with various regimes, doses and routes of opioids, the impact of partial agonists (like buprenorphine) and the clinical significance of the biochemical findings from the HPA axis. Finally, well-designed prospective rather than cross-sectional studies taking into account the effect of confounding factors (like other comorbidities, drugs or pain) are needed to clarify the long-term benefits and risks of hormonal treatment and its effects on other areas, including pain sensitivity and potential reduction in opioid dose, and recovery of patients on methadone for opioid use disorder. These will finally lead to safe and cost-effective clinical guidelines, but until these become available, periodical assessment of the gonadal and adrenal function (particularly when relevant clinical manifestations are present) and evaluation of bone health status are advised.

\section{Declaration of interest}

The authors declare that there is no conflict of interest that could be perceived as prejudicing the impartiality of this review.

\section{Funding}

This research did not receive any specific grant from any funding agency in the public, commercial or not-for-profit sector.

\section{References}

1 Pathan H \& Williams J. Basic opioid pharmacology: an update. British Journal of Pain 20126 11-16. (https://doi. org/10.1177/2049463712438493)

2 Dietis N, Rowbotham DJ \& Lambert DG. Opioid receptor subtypes: fact or artifact? British Journal of Anaesthesia 2011107 8-18. (https:// doi.org/10.1093/bja/aer115)

3 Stein C. Opioid receptors. Annual Review of Medicine $2016 \mathbf{6 7}$ 433-451. (https://doi.org/10.1146/annurev-med-062613-093100)

4 McDonald J \& Lambert DG. Opioid receptors. BJA Education 201515 219-224. (https://doi.org/10.1093/bjaceaccp/mku041)

5 Manchikanti L, Kaye AM, Knezevic NN, McAnally H, Slavin K, Trescot AM, Blank S, Pampati V, Abdi S, Grider JS et al. Responsible, safe, and effective prescription of opioids for chronic non-cancer pain: American Society of Interventional Pain Physicians (ASIPP) guidelines. Pain Physician 201720 S3-S92.

6 Zin CS, Chen LC \& Knaggs RD. Changes in trends and pattern of strong opioid prescribing in primary care. European Journal of Pain 201418 1343-1351. (https://doi.org/10.1002/j.15322149.2014.496.x)

7 Ray WA, Chung CP, Murray KT, Hall K \& Stein CM. Prescription of long-acting opioids and mortality in patients with chronic noncancer pain. JAMA 2016315 2415-2423. (https://doi. org/10.1001/jama.2016.7789)

8 Grossman A, Moult PJ, Cunnah D \& Besser M. Different opioid mechanisms are involved in the modulation of ACTH and gonadotrophin release in man. Neuroendocrinology 198642 357-360. (https://doi.org/10.1159/000124463)

9 Vuong C, Van Uum SH, O’Dell LE, Lutfy K \& Friedman TC. The effects of opioids and opioid analogs on animal and human endocrine systems. Endocrine Reviews 201031 98-132. (https://doi. org/10.1210/er.2009-0009)

10 Mendelson JH, Ellingboe J, Judson BA \& Goldstein A. Plasma testosterone and luteinizing hormone levels during levo-alphaacetylmethadol maintenance and withdrawal. Clinical Pharmacology and Therapeutics 198435 545-547. (https://doi.org/10.1038/ clpt.1984.75)

11 Woody G, McLellan AT, O’Brien C, Persky H, Stevens G, Arndt I $\&$ Carroff S. Hormone secretion in methadone-dependent and abstinent patients. NIDA Research Monograph $1988 \mathbf{8 1}$ 216-223.

12 Roberts LJ, Finch PM, Pullan PT, Bhagat CI \& Price LM. Sex hormone suppression by intrathecal opioids: a prospective study. Clinical Journal of Pain 200218 144-148. (https://doi.org/10.1097/00002508200205000-00002)

13 Daniell HW. Hypogonadism in men consuming sustained-action oral opioids. Journal of Pain 20023 377-384. (https://doi.org/10.1054/ jpai.2002.126790)

14 Daniell HW. Opioid endocrinopathy in women consuming prescribed sustained-action opioids for control of nonmalignant pain. Journal of Pain 20089 28-36. (https://doi.org/10.1016/j. jpain.2007.08.005)

15 Fraser LA, Morrison D, Morley-Forster P, Paul TL, Tokmakejian S, Larry Nicholson R, Bureau Y, Friedman TC \& Van Uum SH. Oral opioids for chronic non-cancer pain: higher prevalence of hypogonadism in men than in women. Experimental and Clinical Endocrinology and Diabetes 2009117 38-43. (https://doi. org/10.1055/s-2008-1076715)

16 Abs R, Verhelst J, Maeyaert J, Van Buyten JP, Opsomer F, Adriaensen H, Verlooy J, Van Havenbergh T, Smet M \& Van Acker K. Endocrine consequences of long-term intrathecal administration of opioids. Journal of Clinical Endocrinology and Metabolism $2000 \mathbf{8 5}$ 2215-2222. (https://doi.org/10.1210/jcem.85.6.6615)

17 Santen FJ, Sofsky J, Bilic N \& Lippert R. Mechanism of action of narcotics in the production of menstrual dysfunction in women. Fertility and Sterility 197526 538-548. (https://doi.org/10.1016/ S0015-0282(16)41173-8)

18 Ragni G, De Lauretis L, Bestetti O, Sghedoni D \& Gambaro V. Gonadal function in male heroin and methadone addicts. International Journal of Andrology 198811 93-100. (https://doi. org/10.1111/j.1365-2605.1988.tb00984.x)

19 Bawor M, Bami H, Dennis BB, Plater C, Worster A, Varenbut M, Daiter J, Marsh DC, Steiner M, Anglin R et al. Testosterone suppression in opioid users: a systematic review and metaanalysis. Drug and Alcohol Dependence 2015149 1-9. (https://doi. org/10.1016/j.drugalcdep.2015.01.038)

20 Cicero TJ, Bell RD, Wiest WG, Allison JH, Polakoski K \& Robins E. Function of the male sex organs in heroin and methadone users. New England Journal of Medicine 1975292 882-887. (https://doi. org/10.1056/NEJM197504242921703)

21 Mendelson JH \& Mello NK. Plasma testosterone levels during chronic heroin use and protracted astinence. A study of Hong Kong addicts. Clinical Pharmacology and Therapeutics 197517 529-533. (https://doi. org/10.1002/cpt1975175529) 
22 Mendelson JH, Mendelson JE \& Patch VD. Plasma testosterone levels in heroin addiction and during methadone maintenance. Journal of Pharmacology and Experimental Therapeutics 1975192 211-217.

23 Mendelson JH, Inturrisi CE, Renault P \& Senay EC. Effects of acetylmethadol on plasma testosterone. Clinical Pharmacology and Therapeutics 197619 371-374. (https://doi.org/10.1002/ cpt1976193371)

24 Pelosi MA, Sama JC, Caterini H \& Kaminetzky HA. Galactorrheaamenorrhea syndrome associated with heroin addiction. American Journal of Obstetrics and Gynecology 1974118 966-970. (https://doi. org/10.1016/0002-9378(74)90667-X)

25 Duarte RV, Raphael JH, Southall JL, Labib MH, Whallett AJ \& Ashford RL. Hypogonadism and low bone mineral density in patients on long-term intrathecal opioid delivery therapy. BMJ Open 20133 e002856. (https://doi.org/10.1136/bmjopen-2013-002856)

26 Finch PM, Roberts LJ, Price L, Hadlow NC \& Pullan PT. Hypogonadism in patients treated with intrathecal morphine. Clinical Journal of Pain 200016 251-254. (https://doi. org/10.1097/00002508-200009000-00011)

27 Paice JA, Penn RD \& Ryan WG. Altered sexual function and decreased testosterone in patients receiving intraspinal opioids. Journal of Pain and Symptom Management 19949 126-131. (https:// doi.org/10.1016/0885-3924(94)90166-X)

28 Rajagopal A, Vassilopoulou-Sellin R, Palmer JL, Kaur G \& Bruera E. Hypogonadism and sexual dysfunction in male cancer survivors receiving chronic opioid therapy. Journal of Pain and Symptom Management 200326 1055-1061. (https://doi.org/10.1016/S08853924(03)00331-2)

29 Rajagopal A, Vassilopoulou-Sellin R, Palmer JL, Kaur G \& Bruera E. Symptomatic hypogonadism in male survivors of cancer with chronic exposure to opioids. Cancer 2004100 851-858. (https://doi. org/10.1002/cncr.20028)

30 Aloisi AM, Aurilio C, Bachiocco V, Biasi G, Fiorenzani P, Pace MC, Paci V, Pari G, Passavanti G, Ravaioli L et al. Endocrine consequences of opioid therapy. Psychoneuroendocrinology 200934 (Supplement 1) S162-S168. (https://doi.org/10.1016/j.psyneuen.2009.05.013)

31 Rubinstein A \& Carpenter DM. Elucidating risk factors for androgen deficiency associated with daily opioid use. American Journal of Medicine 2014127 1195-1201. (https://doi.org/10.1016/j. amjmed.2014.07.015)

32 Rubinstein AL, Carpenter DM \& Minkoff JR. Hypogonadism in men with chronic pain linked to the use of long-acting rather than shortacting opioids. Clinical Journal of Pain 201329 840-845. (https://doi. org/10.1097/AJP.0b013e31827c7b5d)

33 Rubinstein AL \& Carpenter DM. Association between commonly prescribed opioids and androgen deficiency in men: a retrospective cohort analysis. Pain Medicine 201718 637-644. (https://doi. org/10.1093/pm/pnw182)

34 Bliesener N, Albrecht S, Schwager A, Weckbecker K, Lichtermann D $\&$ Klingmuller D. Plasma testosterone and sexual function in men receiving buprenorphine maintenance for opioid dependence. Journal of Clinical Endocrinology and Metabolism 200590 203-206. (https://doi.org/10.1210/jc.2004-0929)

35 Hallinan R, Byrne A, Agho K, McMahon C, Tynan P \& Attia J. Erectile dysfunction in men receiving methadone and buprenorphine maintenance treatment. Journal of Sexual Medicine 20085 684-692. (https://doi.org/10.1111/j.1743-6109.2007.00702.x)

36 Policola C, Stokes V, Karavitaki N \& Grossman A. Adrenal insufficiency in acute oral opiate therapy. Endocrinology Diabetes and Metabolism Case Reports 20142014 130071. (https://doi.org/10.1530/ EDM-13-0071)

37 Mussig K, Knaus-Dittmann D, Schmidt H, Morike K \& Haring HU. Secondary adrenal failure and secondary amenorrhoea following hydromorphone treatment. Clinical Endocrinology 200766 604-605. (https://doi.org/10.1111/j.1365-2265.2007.02779.x)
38 Fleseriu M, Hashim IA, Karavitaki N, Melmed S, Murad MH, Salvatori R \& Samuels MH. Hormonal replacement in hypopituitarism in adults: an endocrine society clinical practice guideline. Journal of Clinical Endocrinology and Metabolism 2016101 3888-3921. (https://doi.org/10.1210/jc.2016-2118)

39 Aloisi AM, Ceccarelli I, Carlucci M, Suman A, Sindaco G, Mameli S, Paci V, Ravaioli L, Passavanti G, Bachiocco V et al. Hormone replacement therapy in morphine-induced hypogonadic male chronic pain patients. Reproductive Biology and Endocrinology 20119 26. (https://doi.org/10.1186/1477-7827-9-26)

40 Daniell HW, Lentz R \& Mazer NA. Open-label pilot study of testosterone patch therapy in men with opioid-induced androgen deficiency. Journal of Pain 20067 200-210. (https://doi.org/10.1016/j. jpain.2005.10.009)

41 Basaria S, Travison TG, Alford D, Knapp PE, Teeter K, Cahalan C, Eder R, Lakshman K, Bachman E, Mensing G et al. Effects of testosterone replacement in men with opioid-induced androgen deficiency: a randomized controlled trial. Pain 2015156 280-288. (https://doi.org/10.1097/01.j.pain.0000460308.86819.aa)

42 Huang G, Travison T, Maggio M, Edwards RR \& Basaria S. Effects of testosterone replacement on metabolic and inflammatory markers in men with opioid-induced androgen deficiency. Clinical Endocrinology 201685 232-238. (https://doi.org/10.1111/cen.13049)

43 Glahn A, Heberlein A, Dursteler-MacFarland KM, Lenz B, Frieling H, Groschl M, Wiesbeck GA, Kornhuber J, Bonsch D, Bleich S et al. Atrial natriuretic peptide, arginine vasopressin peptide and cortisol serum levels in opiate-dependent patients. Neuropsychobiology 2013 67 111-115. (https://doi.org/10.1159/000346110)

44 Tsagarakis S, Navarra P, Rees LH, Besser M, Grossman A \& Navara P. Morphine directly modulates the release of stimulated corticotrophin-releasing factor-41 from rat hypothalamus in vitro. Endocrinology 1989124 2330-2335. (https://doi.org/10.1210/endo124-5-2330)

45 Allolio B, Schulte HM, Deuss U, Kallabis D, Hamel E \& Winkelman W. Effect of oral morphine and naloxone on pituitaryadrenal response in man induced by human corticotropin-releasing hormone. Acta Endocrinologica 1987114 509-514. (https://doi. org/10.1530/acta.0.1140509)

46 Rittmaster RS, Cutler GB Jr, Sobel DO, Goldstein DS, Koppelman MC, Loriaux DL \& Chrousos GP. Morphine inhibits the pituitary-adrenal response to ovine corticotropin-releasing hormone in normal subjects. Journal of Clinical Endocrinology and Metabolism 198560 891-895. (https://doi.org/10.1210/jcem-60-5-891)

47 Conaglen JV, Donald RA, Espiner EA, Livesey JH \& Nicholls MG. Effect of naloxone on the hormone response to CRF in normal man. Endocrine Research 198511 39-44. (https://doi. org/10.3109/07435808509035423)

48 Schluger JH, Ho A, Borg L, Porter M, Maniar S, Gunduz M, Perret G, King A \& Kreek MJ. Nalmefene causes greater hypothalamicpituitary-adrenal axis activation than naloxone in normal volunteers: implications for the treatment of alcoholism. Alcoholism, Clinical and Experimental Research 199822 1430-1436. (https://doi. org/10.1111/j.1530-0277.1998.tb03931.x)

49 Pfeiffer A, Knepel W, Braun S, Meyer HD, Lohmann H \& Brantl V. Effects of a kappa-opioid agonist on adrenocorticotropic and diuretic function in man. Hormone and Metabolic Research 198618 842-848. (https://doi.org/10.1055/s-2007-1012453)

50 Napier C, Gan EH \& Pearce SH. Loperamide-induced hypopituitarism. BMJ Case Reports 2016 2016. (https://doi. org/10.1136/bcr-2016-216384)

51 Lee AS \& Twigg SM. Opioid-induced secondary adrenal insufficiency presenting as hypercalcaemia. Endocrinology Diabetes and Metabolism Case Reports 20152015 150035. (https://doi.org/10.1530/EDM-15-0035)

52 Das G. Chronic heroin dependence leading to adrenal insufficiency. Case Reports in Endocrinology 20142014 461816. (https://doi. org/10.1155/2014/461816) 
53 Debono M, Chan S, Rolfe C \& Jones TH. Tramadol-induced adrenal insufficiency. European Journal of Clinical Pharmacology 201167 865-867. (https://doi.org/10.1007/s00228-011-0992-9)

54 Oltmanns KM, Fehm HL \& Peters A. Chronic fentanyl application induces adrenocortical insufficiency. Journal of Internal Medicine 2005 257 478-480. (https://doi.org/10.1111/j.1365-2796.2005.01483.x)

55 Ducat E, Ray B, Bart G, Umemura Y, Varon J, Ho A \& Kreek MJ. Mu-opioid receptor A118G polymorphism in healthy volunteers affects hypothalamic-pituitary-adrenal axis adrenocorticotropic hormone stress response to metyrapone. Addiction Biology 201318 325-331. (https://doi.org/10.1111/j.1369-1600.2011.00313.x)

56 Chong RY, Oswald L, Yang X, Uhart M, Lin PI \& Wand GS. The mu-opioid receptor polymorphism A118G predicts cortisol responses to naloxone and stress. Neuropsychopharmacology 200631 204-211. (https://doi.org/10.1038/sj.npp.1300856)

57 Coiro V, Volpi R, Stella A, Venturi N \& Chiodera P. Stimulatory effect of naloxone on plasma cortisol in human: possible direct stimulatory action at the adrenal cortex. Regulatory Peptides 2011166 1-2. (https://doi.org/10.1016/j.regpep.2010.08.008)

58 Clarke D, Fearon U, Cunningham SK \& McKenna TJ. The steroidogenic effects of beta-endorphin and joining peptide: a potential role in the modulation of adrenal androgen production. Journal of Endocrinology 1996151 301-307. (https://doi.org/10.1677/joe.0.1510301)

59 el Daly ES. Influence of acute and chronic morphine or stadol on the secretion of adrenocorticotrophin and its hypothalamic releasing hormone in the rat. Life Sciences 199659 1881-1890. (https://doi. org/10.1016/S0024-3205(96)00535-8)

60 Buckingham JC \& Cooper TA. Differences in hypothalamo-pituitaryadrenocortical activity in the rat after acute and prolonged treatment with morphine. Neuroendocrinology 198438 411-417. (https://doi. org/10.1159/000123927)

61 Radahmadi M, Sharifi MR, Amini M \& Fesharaki M. Effect of the co-administration of glucose with morphine on glucoregulatory hormones and causing of diabetes mellitus in rats. Advanced Biomedical Research 20165 21. (https://doi.org/10.4103/22779175.175907)

62 Ferenczi S, Nunez C, Pinter-Kubler B, Foldes A, Martin F, Markus VL, Milanes MV \& Kovacs KJ. Changes in metabolic-related variables during chronic morphine treatment. Neurochemistry International 201057 323-330. (https://doi.org/10.1016/j.neuint.2010.06.011)

63 Bershad AK, Jaffe JH, Childs E \& de Wit H. Opioid partial agonist buprenorphine dampens responses to psychosocial stress in humans. Psychoneuroendocrinology 201552 281-288. (https://doi. org/10.1016/i.psyneuen.2014.12.004)

64 Watanabe K, Kashiwagi K, Kamiyama T, Yamamoto M, Fukunaga M, Inada E \& Kamiyama Y. High-dose remifentanil suppresses stress response associated with pneumoperitoneum during laparoscopic colectomy. Journal of Anesthesia 201428 334-340. (https://doi. org/10.1007/s00540-013-1738-x)

65 Facchinetti F, Volpe A, Farci G, Petraglia F, Porro CA, Barbieri G, Cioni A, Balestrieri A \& Genazzani AR. Hypothalamus-pituitaryadrenal axis of heroin addicts. Drug and Alcohol Dependence 198515 361-366. (https://doi.org/10.1016/0376-8716(85)90014-6)

66 Lovallo WR, King AC, Farag NH, Sorocco KH, Cohoon AJ \& Vincent AS. Naltrexone effects on cortisol secretion in women and men in relation to a family history of alcoholism: studies from the Oklahoma Family Health Patterns Project. Psychoneuroendocrinology 201237 1922-1928. (https://doi.org/10.1016/j. psyneuen.2012.04.006)

67 Roche DJ, Childs E, Epstein AM \& King AC. Acute HPA axis response to naltrexone differs in female vs. male smokers. Psychoneuroendocrinology 201035 596-606. (https://doi. org/10.1016/j.psyneuen.2009.09.016)

68 Uhart M, Chong RY, Oswald L, Lin PI \& Wand GS. Gender differences in hypothalamic-pituitary-adrenal (HPA) axis reactivity. Psychoneuroendocrinology 200631 642-652. (https://doi. org/10.1016/j.psyneuen.2006.02.003)

69 Roche DJ \& King AC. Sex differences in acute hormonal and subjective response to naltrexone: the impact of menstrual cycle phase. Psychoneuroendocrinology 201552 59-71. (https://doi. org/10.1016/j.psyneuen.2014.10.013)

70 Gerber H, Borgwardt SJ, Schmid O, Gerhard U, Joechle W, RiecherRossler A, Wiesbeck GA \& Walter M. The impact of diacetylmorphine on hypothalamic-pituitary-adrenal axis activity and heroin craving in heroin dependence. European Addiction Research 201218 116-123. (https://doi.org/10.1159/000334411)

71 Facchinetti F, Grasso A, Petraglia F, Parrini D, Volpe A \& Genazzani AR. Impaired circadian rhythmicity of beta-lipotrophin, beta-endorphin and ACTH in heroin addicts. Acta Endocrinologica 1984105 149-155. (https://doi.org/10.1530/acta.0.1050149)

72 McCain GA \& Tilbe KS. Diurnal hormone variation in fibromyalgia syndrome: a comparison with rheumatoid arthritis. Journal of Rheumatology 198919 154-157.

73 Griep EN, Boersma JW, Lentjes EG, Prins AP, van der Korst JK \& de Kloet ER. Function of the hypothalamic-pituitary-adrenal axis in patients with fibromyalgia and low back pain. Journal of Rheumatology 199825 1374-1381.

74 Gibb FW, Stewart A, Walker BR \& Strachan MW. Adrenal insufficiency in patients on long-term opioid analgesia. Clinical Endocrinology 201685 831-835. (https://doi.org/10.1111/cen.13125)

75 Valverde-Filho J, da Cunha Neto MB, Fonoff ET, Meirelles Ede S $\&$ Teixeira MJ. Chronic spinal and oral morphine-induced neuroendocrine and metabolic changes in noncancer pain patients. Pain Medicine 201516 715-725. (https://doi.org/10.1111/pme.12661)

76 Daniell HW. DHEAS deficiency during consumption of sustainedaction prescribed opioids: evidence for opioid-induced inhibition of adrenal androgen production. Journal of Pain 20067 901-907. (https://doi.org/10.1016/j.jpain.2006.04.011)

77 Nenke MA, Haylock CL, Rankin W, Inder WJ, Gagliardi L, Eldridge C, Rolan P \& Torpy DJ. Low-dose hydrocortisone replacement improves wellbeing and pain tolerance in chronic pain patients with opioidinduced hypocortisolemic responses. A pilot randomized, placebocontrolled trial. Psychoneuroendocrinology 201556 157-167. (https:// doi.org/10.1016/j.psyneuen.2015.03.015)

78 Singh M, Simpkins JW, Layden MP, Romano TM \& Millard WJ. Opiate modulation of growth hormone secretion is compromised during the steroid-induced luteinizing hormone surge. Neuroendocrinology 199255 214-220. (https://doi. org/10.1159/000126117)

79 Bartolome MB \& Kuhn CM. Endocrine effects of methadone in rats; acute effects in adults. European Journal of Pharmacology 198395 231-238. (https://doi.org/10.1016/0014-2999(83)90639-8)

80 Armstrong JD \& Spears JW. Changes in growth hormone and luteinizing hormone following acute or chronic administration of an opioid agonist, FK33-824, in wethers. Journal of Animal Science 1991 69 774-781. (https://doi.org/10.2527/1991.692774x)

81 Ceger P \& Kuhn CM. Opiate withdrawal in the neonatal rat: relationship to duration of treatment and naloxone dose. Psychopharmacology 2000150 253-259. (https://doi.org/10.1007/ s002130000413)

82 Muller EE, Locatelli V \& Cocchi D. Neuroendocrine control of growth hormone secretion. Physiological Reviews 199979 511-607. (https://doi.org/10.1152/physrev.1999.79.2.511)

83 Eason MG, Francis RS \& Kuhn CM. mu-Opioid agonists stimulate growth hormone secretion in immature rats. Neuroendocrinology 1996 63 489-497. (https://doi.org/10.1159/000127077)

84 Janik J, Klosterman S, Parman R \& Callahan P. Multiple opiate receptor subtypes are involved in the stimulation of growth hormone release by beta-endorphin in female rats. Neuroendocrinology 199460 69-75. (https://doi.org/10.1159/000126721) 
85 Willoughby JO \& Medvedev A. Opioid receptor activation resets the hypothalamic clock generating growth hormone secretory bursts in the rat. Journal of Endocrinology 1996148 149-155. (https://doi. org/10.1677/joe.0.1480149)

86 Miki N, Ono M \& Shizume K. Evidence that opiatergic and alphaadrenergic mechanisms stimulate rat growth hormone release via growth hormone-releasing factor (GRF). Endocrinology 1984114 1950-1952. (https://doi.org/10.1210/endo-114-5-1950)

87 Wehrenberg WB, Bloch B \& Ling N. Pituitary secretion of growth hormone in response to opioid peptides and opiates is mediated through growth hormone-releasing factor. Neuroendocrinology 1985 41 13-16. (https://doi.org/10.1159/000124147)

88 Drouva SV, Epelbaum J, Tapia-Arancibia L, Laplante E \& Kordon C. Opiate receptors modulate LHRH and SRIF release from mediobasal hypothalamic neurons. Neuroendocrinology 198132 163-167. (https://doi.org/10.1159/000123150)

89 Borer KT, Nicoski DR \& Owens V. Alteration of pulsatile growth hormone secretion by growth-inducing exercise: involvement of endogenous opiates and somatostatin. Endocrinology 1986118 844-850. (https://doi.org/10.1210/endo-118-2-844)

90 Dobado-Berrios PM, Li S, Garcia de Yebenes E \& Pelletier G. Effects of morphine and naloxone on prolactin and growth hormone gene expression in the male rat pituitary gland. Journal of Neuroendocrinology 19935 553-556. (https://doi. org/10.1111/j.1365-2826.1993.tb00521.x)

91 Simpkins JW, Millard WJ \& Berglund LA. Effects of chronic stimulation or antagonism of opiate receptors on GH secretion in male and female rats. Life Sciences 199352 1443-1450. (https://doi. org/10.1016/0024-3205(93)90068-E)

92 Bhansali A, Velayutham P, Sialy R \& Sethi B. Effect of opiates on growth hormone secretion in acromegaly. Hormone and Metabolic Research 200537 425-427. (https://doi.org/10.1055/s-2005-870230)

93 Delitala G, Tomasi PA, Palermo M, Ross RJ, Grossman A \& Besser GM. Opioids stimulate growth hormone $(\mathrm{GH})$ release in man independently of GH-releasing hormone. Journal of Clinical Endocrinology and Metabolism 198969 356-358. (https://doi. org/10.1210/jcem-69-2-356)

94 Hemmings R, Fox G \& Tolis G. Effect of morphine on the hypothalamic-pituitary axis in postmenopausal women. Fertility and Sterility 198237 389-391. (https://doi.org/10.1016/S00150282(16)46101-7)

95 Tolis G, Hickey J \& Guyda H. Effects of morphine on serum growth hormone, cortisol, prolactin and thyroid stimulating hormone in man. Journal of Clinical Endocrinology and Metabolism 197541 797-800. (https://doi.org/10.1210/jcem-41-4-797)

96 Barbarino A, De Marinis L, Mancini A, D’Amico C, Passeri M, Zuppi P, Sambo P \& Tofani A. Sex-related naloxone influence on growth hormone-releasing hormone-induced growth hormone secretion in normal subjects. Metabolism: Clinical and Experimental 198736 105-109. (https://doi.org/10.1016/0026-0495(87)90001-1)

97 Tomasi PA, Fanciulli G, Palermo M, Pala A, Demontis MA \& Delitala G. Opioid-receptor blockade blunts growth hormone (GH) secretion induced by GH-releasing hormone in the human male. Hormone and Metabolic Research 199830 34-36. (https://doi. org/10.1055/s-2007-978827)

98 Cushman P Jr Growth hormone in narcotic addiction. Journal of Clinical Endocrinology and Metabolism 197235 352-358. (https://doi. org/10.1210/jcem-35-3-352)

99 Merza Z, Edwards N, Walters SJ, Newell-Price J \& Ross RJ. Patients with chronic pain and abnormal pituitary function require investigation. Lancet 2003361 2203-2204. (https://doi.org/10.1016/ S0140-6736(03)13775-0)

100 Dobson PR \& Brown BL. Involvement of the hypothalamus in opiate-stimulated prolactin secretion. Regulatory Peptides 198820 305-310. (https://doi.org/10.1016/0167-0115(88)90065-1)
101 Delitala G, Grossman A \& Besser GM. The participation of hypothalamic dopamine in morphine-induced prolactin release in man. Clinical Endocrinology 198319 437-444. (https://doi. org/10.1111/j.1365-2265.1983.tb00017.x)

102 Moshtaghi-Kashanian GR, Esmaeeli F \& Dabiri S. Enhanced prolactin levels in opium smokers. Addiction Biology 200510 345-349. (https:// doi.org/10.1080/13556210500351263)

103 Chan V, Wang C \& Yeung RT. Effects of heroin addiction on thyrotrophin, thyroid hormones and porlactin secretion in men. Clinical Endocrinology 197910 557-565. (https://doi. org/10.1111/j.1365-2265.1979.tb02115.x)

104 Rhodin A, Stridsberg M \& Gordh T. Opioid endocrinopathy: a clinical problem in patients with chronic pain and long-term oral opioid treatment. Clinical Journal of Pain 201026 374-380. (https://doi. org/10.1097/AJP.0b013e3181d1059d)

105 Wong D, Gray DP, Simmonds M, Rashiq S, Sobolev I \& Morrish DW. Opioid analgesics suppress male gonadal function but opioid use in males and females does not correlate with symptoms of sexual dysfunction. Pain Research and Management 201116 311-316. (https://doi.org/10.1155/2011/807123)

106 de la Rosa RE \& Hennessey JV. Hypogonadism and methadone: hypothalamic hypogonadism after long-term use of high-dose methadone. Endocrine Practice 19962 4-7. (https://doi.org/10.4158/ EP.2.1.4)

107 Vescovi PP, Pezzarossa A, Ceresini G, Rastelli G, Valenti G \& Gerra G. Effects of dopamine receptor stimulation on opiate-induced modifications of pituitary-gonadal function. Hormone Research 1985 21 155-159. (https://doi.org/10.1159/000180040)

108 Judd AM \& Hedge GA. The roles of opioid peptides in controlling thyroid stimulating hormone release. Life Sciences 198231 2529-2536. (https://doi.org/10.1016/0024-3205(82)90760-3)

109 del Valle-Soto ME, Iglesias L, Calzada B, Vega JA, Hernandez LC \& Perez-Casas A. Effects of morphine on the pituitary-thyroid axis: morphological and analytical studies. Functional and Developmental Morphology 19911 3-6.

110 Devilla L, Pende A, Morgano A, Giusti M, Musso NR \& Lotti G. Morphine-induced TSH release in normal and hypothyroid subjects. Neuroendocrinology 198540 303-308. (https://doi. org/10.1159/000124091)

111 Brambilla F, Nobile P, Zanoboni A, Zanoboni-Muciaccia W \& Meroni PL. Effects of chronic heroin addiction on pituitary-thyroid function in man. Journal of Endocrinological Investigation 19803 251-255. (https://doi.org/10.1007/BF03348271)

112 Merdin A, Merdin FA, Gunduz S, Bozcuk H \& Coskun HS. Opioid endocrinopathy: a clinical problem in patients with cancer pain. Experimental and Therapeutic Medicine 201611 1819-1822.

113 Zerbe RL, Henry DP \& Robertson GL. A new Met-enkephalin analogue suppresses plasma vasopressin in man. Peptides 19823 199-201. (https://doi.org/10.1016/0196-9781(82)90051-1)

114 Kramer HJ, Uhl W, Ladstetter B \& Backer A. Influence of asimadoline, a new kappa-opioid receptor agonist, on tubular water absorption and vasopressin secretion in man. British Journal of Clinical Pharmacology 200050 227-235. (https://doi.org/10.1046/j.13652125.2000.00256.x)

115 Weiskopf RB, Reid IA, Fisher DM, Holmes MA, Rosen JI \& Keil LC. Effects of fentanyl on vasopressin secretion in human subjects. Journal of Pharmacology and Experimental Therapeutics 1987242 970-973.

116 Kokko H, Hall PD \& Afrin LB. Fentanyl-associated syndrome of inappropriate antidiuretic hormone secretion. Pharmacotherapy 2002 22 1188-1192. (https://doi.org/10.1592/phco.22.13.1188.33526)

117 Boulton AJ, Wilson N, Turnbull KW \& Yip RW. Haemodynamic and plasma vasopressin responses during high-dose fentanyl or sufentanil anaesthesia. Canadian Anaesthetists Society Journal 198633 475-483. (https://doi.org/10.1007/BF03010974) 
118 Korinek AM, Languille M, Bonnet F, Thibonnier M, Sasano P, Lienhart A \& Viars P. Effect of postoperative extradural morphine on ADH secretion. British Journal of Anaesthesia $1985 \mathbf{5 7} 407-411$. (https://doi.org/10.1093/bja/57.4.407)

119 Bozkurt P, Kaya G, Yeker Y, Altintas F, Bakan M, Hacibekiroglu M $\&$ Kavunoglu G. Effects of systemic and epidural morphine on antidiuretic hormone levels in children. Paediatric Anaesthesia 2003 13 508-514. (https://doi.org/10.1046/j.1460-9592.2003.01096.x)

120 Daniell HW. Opioid osteoporosis. Archives of Internal Medicine 2004164 338; author reply 338. (https://doi.org/10.1001/ archinte.164.3.338-a)

121 Pedrazzoni M, Vescovi PP, Maninetti L, Michelini M, Zaniboni G, Pioli G, Costi D, Alfano FS \& Passeri M. Effects of chronic heroin abuse on bone and mineral metabolism. Acta Endocrinologica 1993 129 42-45. (https://doi.org/10.1530/acta.0.1290042)
122 Grey A, Rix-Trott K, Horne A, Gamble G, Bolland M \& Reid IR. Decreased bone density in men on methadone maintenance therapy. Addiction 2011106 349-354. (https://doi.org/10.1111/j.13600443.2010.03159.x)

123 Kinjo M, Setoguchi S, Schneeweiss S \& Solomon DH. Bone mineral density in subjects using central nervous system-active medications. American Journal of Medicine 20051181414.

124 Vestergaard P, Rejnmark L \& Mosekilde L. Fracture risk associated with the use of morphine and opiates. Journal of Internal Medicine 2006260 76-87. (https://doi.org/10.1111/j.1365-2796.2006. 01667.x)

125 Li L, Setoguchi S, Cabral H \& Jick S. Opioid use for noncancer pain and risk of fracture in adults: a nested case-control study using the general practice research database. American Journal of Epidemiology 2013178 559-569. (https://doi.org/10.1093/aje/kwt013)

Received 31 March 2018

Revised version received 21 June 2018

Accepted 4 July 2018 